\title{
HUBUNGAN STATUS GIZI DENGAN KELELAHAN KERJA SUBJEKTIF PADA POLISI LALU LINTAS DI KOTA PADANG TAHUN 2018
}

\author{
Yulia $^{1}$ Afzahul Rahmi ${ }^{2}$ \\ ${ }^{1}$ S-1 Kesehatan Masyarakat STIKes Alifah Padang, Indonesia \\ Email :yuliaskm88@gmail.com \\ ${ }^{2}$ S-1 Kesehatan Masyarakat STIKes Alifah Padang, Indonesia \\ afzahul_rahmi@yahoo.co.id
}

\begin{abstract}
ABSTRAK
Laporan Departemen Tenaga Kerja tahun 2013 bahwa 27,8\% kecelakaan kerja disebabkan oleh kelelahan yang cukup tinggi dimana 9,5\% kecelakaan tersebut mengakibatkan kecacatan. Berdasarkan hasil survei awal diperoleh bahwa sebagian besar polisi lalu lintas berada pada shif siang, memiliki status gizi tidak normal dan usia lebih dari 35 tahun sebesar 66,7\% dan semua responden memiliki masa kerja lebih dari 10 tahun dan memiliki kelelahan kerja subjektif. Jenis penelitian ini adalah kuantitatif dengan desain cross sectional. Populasi penelitian ini adalah seluruh polisi lalu lintas yang berada di pos jaga. Metode pengambilan sampel adalah accidental sampling selama satu minggu, diperoleh 30 responden. Berdasarkan uji univariat, proporsi karakteristik polisi lalu lintas di Kota yang menjadi responden adalah adalaj $66,7 \%$ memliki usia lebih dari 35 tahun, 60,0\% masa kerja lebih dari 10 tahun, 57,6\% shift kerja siang, status gizi tidak normal adalah 57,6\% dan tingkat kelelahan kerja subjektif tinggi 73,3\% dimana semua polisi lalu lintas selalu merasa haus, malas berbicara dan berat di kaki. Berdasarkan Uji Korelasi Kendal Tau dengan interval kepercayaan 95\% diperoleh bahwa ada hubungan positif kuat antara status gizi dengan kelelahan kerja subjektif polisi lalu lintas di Kota Padang Tahun 2018. Disarankan kepada polisi lalu lintas untuk melakukan olah raga pagi sebelum melakukan rutinitas, minum air putih yang cukup, dan mulai mengatur pola konsumsi yang tepat.
\end{abstract}

\section{Kata Kunci: Status Gizi, Kelelahan Kerja Subjektif, Uji Korelasi Kendal Tau}

\section{ABSTRACT}

Manpower and Transmigration office's report in 2013 that $27.8 \%$ of work accidents were caused by exhaution which was quite high that $9.5 \%$ of these accidents resulted in disability. Based on the results of the initial survey, it was found that most of the traffic police were on day shift, had abnormal nutritional status, had a age of more 35 years and $66.7 \%$ and all respondents had a working period of more 10 years and had subjective work exhaustion. This type of research is quantitative with cross sectional design. The population of this study were all traffic police in the guard post. The sampling method is accidental sampling for one week, obtained 30 respondents. Based on the univariate test, the proportion of the characteristics of the traffic police in Padang who respondents were $66.7 \%$ having the age of more 35 years, $60.0 \%$ working period more 10 years, $57.6 \%$ of day shift work, abnormal nutritional status was $56.7 \%$ and the level of subjective work exhaution is $73.3 \%$ where all traffic police always feel thirsty, lazy to talk and heavy on the feet. Based on the Kendall's Tau Coefficient with confidence intervals 95\% obtained there is a strong positive relationship between nutritional status and subjective work exhaustion of the traffic police in Padang in 2018. It is recommended that Padang Police should start implementing work nutrition in the traffic police and it is suggested to the traffic police to do morning exercise before doing the routine, drinking enough water, and starting to set the right consumption pattern.

Keywords: Nutritional Status, Subjective Work Exhaution, Kendall's Tau Coefficient 


\section{PENDAHULUAN}

Salah satu permasalahan umum yang sering ditemukan pada pekerja adalah kelelahan kerja. Kelelahan memiliki arti tersendiri dan bersifat subjektif bagi setiap orang. Kelelahan dapat mengakibatkan terjadinya kecelakaan kerja. Kelelahan kerja juga berhubungan dengan produktivitas tenaga kerja bagian tenun berdasarkan hasil penelitian Muizuddin (2013) di PT Kaltex Tegal.

Menurut Tarwaka (2004) kelelahan merupakan mekanisme perlindungan tubuh agar tubuh terhindar dari kerusakan lebih lanjut. Berdasarkan laporan Departemen Tenaga Kerja tahun 2013 bahwa 27,8\% kecelakaan kerja disebabkan oleh kelelahan yang cukup tinggi dimana 9,5\% kecelakaan tersebut mengakibatkan kecacatan.

Beberapa faktor risiko yang mempengaruhi terjadinya kelelahan kerja adalah usia, massa kerja, status gizi, beban kerja dan riwayat penyakit. Menurut penelitian Iqbal diperoleh bahwa ada hubungan status gizi dengan kelelahan kerja pada karyawan bagian pemuatan di PT Semen Padang tahu 2014 dimana 75\% responden yang mengalami kelelahan kerja memiliki status gizi yang tidak normal. Berdasarkan hasil penelitian Russeng (2009) pada pengemudi bus yang shift malam di Sulawesi Selatan dan Barat diperoleh ada hubungan status gizi dengan kelelahan kerja yang mengakibatkan kejadian mengantuk saat bekerja.

Salah satu pekerjaan yang berpotensi untuk mengalami kelelahan kerja adalah polisi lalu lintas. Polisi lalu lintas merupakan kesatuan yang bertugas memelihara keamanan, memberikan perlindungan dan menciptakan ketertiban lalu lintas sesuai dengan peraturan perundang-undangan. Responden penelitian ini adalah polisi lalu lintas yang bertugas mengatur lalu lintas pergerakkan kendaraan, orang dan hewan di jalan umum yang memiliki lalu lintas padat di Polresta Padang. Polisi lalu lintas bertugas dengan posisi berdiri selama jam kerjanya terutama pada saat jalan umum panas dan padat asap kendaraan.

Berdasarkan survei awal yang dilakukan pada tanggal 12 Juli 2018 dilakukan wawancara pada polisi lalu lintas sebanyak 3 orang polisi diperoleh sebagian besar polisi lalu lintas berada pada shif siang, memiliki status gizi tidak normal, memiliki usia $<35$ tahun sebesar $66,7 \%$ dan semua respoden memiliki masa kerja > 10 tahun dan memiliki kelelahan kerja subjektif. Berdasarkan latar belakang diatas maka dilakukan penelitian untuk melihat hubungan status gizi dengan kelelahan kerja pada Polisi Lalu Lintas di Kota Padang.

Berdasarkan latar belakang diatas maka tujuan penelitian ini adalah untuk diketahuinya hubungan status gizi dengan kelelahan kerja subjektif pada polisi lalu lintas di Kota Padang tahun 2018.

\section{METODE PENELITIAN}

Jenis penelitian yang telah dilakukan untuk melihat hubungan status gizi terhadap kelelahan kerja subjektif pada polisi lalu lintas di Kota Padang Tahun 2018 adalah analitik kuantitatif dengan desain penelitian cross sectional.

Populasi penelitian ini adalah seluruh polisi lalu lintas di Kota Padang. Sampel penelitian ini diambil secara accidental sampling selama 1 minggu dimana semua Besar sampel penelitian ini yang telah diperoleh adalah 30 responden. Polisi Lalu Lintas yang memenuhi kriteria inklusi dan eksklusi yang ditemukan selama satu minggu dijadikan sampel. Adapun kriteria sebagai berikut :

1.Kriteria inklusi penelitian ini adalah semua polisi lalu lintas yang berada di Pos pada saat pengumpulan data dan bersedia menjadi responden.

2. Kriteria ekslusi penelitian ini adalah polisi lalu lintas yang telah menjadi responden sebelumnya. 
Penelitian ini dilakukan mulai dari Bulan Juli sampai dengan Agustus 2018 di Kota Padang dimana tempat pengumpulan data adalah beberapa pos polisi lalu lintas di Kota Padang. Pengumpulan data dilakukan mulai tanggal 20 Juli sampai dengan 30 Juli 2018.

Data penelitian ini diolah dengan menggunakan analisis univariat dan bivariat untuk melihat hubungan status gizi dengan kelelahan kerja subjektif polisi lalu lintas di Kota Padang. Analisis univariat digunakan untuk memperoleh gambaran proporsi karakteristik (usia, masa kerja, dan shift kerja), status gizi, dan kelelahan subjektif polisi lalu lintas. Analisis bivariat untuk melihat hubungan status gizi dengan kelelahan kerja subjektif polisi lalu lintas dengan menggunakan uji Korelasi Kendal Tau dengan tingkat kepercayaan $95 \%$.

\section{Gambar 1}

Gizi Seimbang

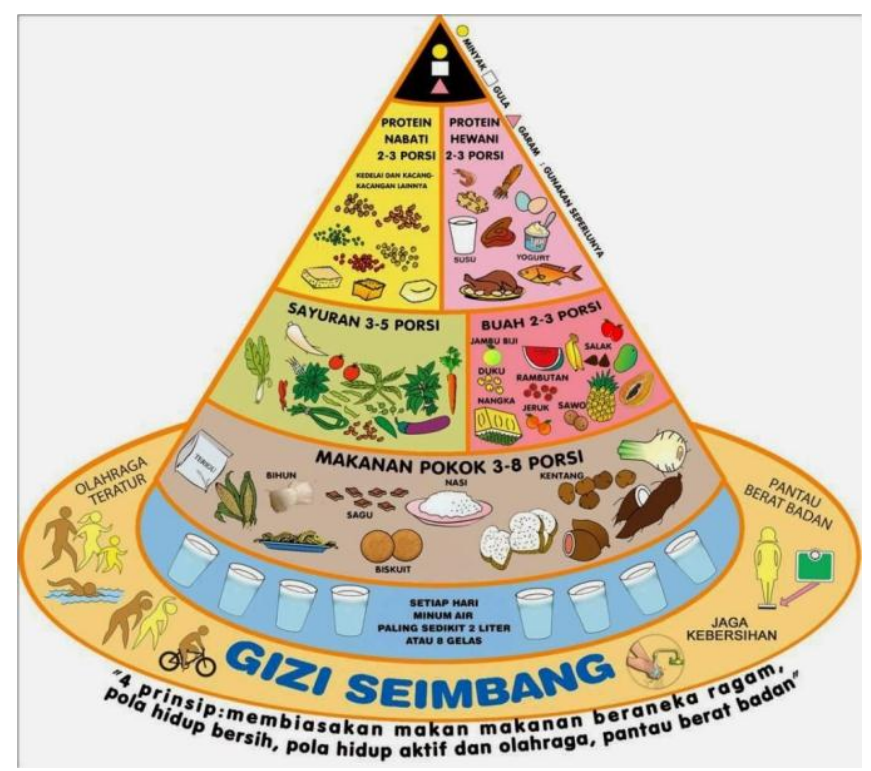

\section{HASIL}

1. Karakteristik Polisi Lalu Lintas

Distribusi proporsi karakteristk polisi lalu lintas yang menjadi responden berdasarkan usia, masa kerja, dan shift kerja dapat dilihat pada Tabel 1.

Tabel 1

Distribusi Proporsi Responden Berdasarkan Usia, Masa Kerja dan Shift Kerja Pada Polisi Lalu Lintas di Kota Padang Tahun 2018

\begin{tabular}{llcc}
\hline & Karakteristik Responden & Frekuensi & Proporsi \\
\hline a. & Usia & 20 & \\
\hline & $<35$ Tahun & 10 & 66,7 \\
& $\geq 35$ Tahun & & 33,3 \\
\hline b. & Masa Kerja & 5 & 40,0 \\
\hline & $\leq 10$ Tahun & 25 & 60,0 \\
& $>10$ Tahun & & \\
\hline c. $\quad$ Shift Kerja & 13 & 43,3 \\
\hline & Pagi & 17 & 57,6 \\
\hline & Siang & $\mathbf{3 0}$ & $\mathbf{1 0 0 , 0}$ \\
\hline
\end{tabular}


2. Status Gizi

Distribusi proporsi polisi lalu lintas yang menjadi responden berdasarkan status gizi dapat dilihat pada Tabel 2.

Tabel 2

Distribusi Proporsi Responden Berdasarkan Status Gizi Pada Polisi Lalu Lintas di Kota Padang Tahun 2018

\begin{tabular}{lcc}
\hline \multicolumn{1}{c}{ Status Gizi } & Frekuensi & Proporsi \\
\hline Normal & 13 & 43,3 \\
Tidak Normal & 17 & 56,7 \\
\hline Jumlah & 30 & 100,0 \\
\hline
\end{tabular}

3. Kelelahan Kerja Subjektif

Distribusi proporsi polisi lalu lintas di Kota Padang yang menjadi responden berdasarkan kelelahan kerja subjektif dapat dilihat pada Tabel 3

Tabel 3

Distribusi Proporsi Responden Berdasarkan Tingkat Kelelahan Kerja Subjektif Pada Polisi Lalu Lintas di Kota Padang Tahun 2018

\begin{tabular}{ccc}
\hline Kelelahan Kerja Subjektif & Frekuensi & Proporsi \\
\hline Rendah & 8 & 26,7 \\
Tinggi & 22 & 73,3 \\
\hline Jumlah & 60 & 100,0 \\
\hline
\end{tabular}

4. Hubungan Status Gizi dengan Kelelahan Kerja Subjektif

Hubungan status gizi polisi lalu lintas di Kota Padang yang menjadi responden dengan kelelahan kerja subjektif dapat dilihat pada tabel 4

Tabel 4

Hubungan Status Gizi Dengan Kelelahan Kerja Subjektif Pada Polisi Lalu Lintas Di Kota Padang Tahun 2018

\begin{tabular}{|c|c|c|c|c|c|c|c|}
\hline \multirow{3}{*}{ Status Gizi } & \multicolumn{4}{|c|}{ Kelelahan Subjektif } & \multirow{2}{*}{\multicolumn{2}{|c|}{ Total }} & \multirow{3}{*}{$T / Z$} \\
\hline & \multicolumn{2}{|c|}{ Rendah } & \multicolumn{2}{|c|}{ Tinggi } & & & \\
\hline & $\mathbf{f}$ & $\%$ & f & $\%$ & $\mathbf{f}$ & $\%$ & \\
\hline Normal & 6 & 46,2 & 7 & 53,8 & 13 & 100,0 & \\
\hline Tidak Normal & 2 & 11,8 & 15 & 88,2 & 17 & 100,0 & $0,736 / 3,2$ \\
\hline Jumlah & 8 & & 22 & & 30 & & \\
\hline
\end{tabular}

\section{PEMBAHASAN}

1. Karakteristik Polisi Lalu Lintas 
Berdasarkan hasil penelitian sebagian besar proporsi karakteristik polisi lalu lintas di Kota Padang yang menjadi responden adalah memiliki umur lebih 35 tahun sebesar 66,7\%, masa kerja lebih 10 tahun sebesar $60 \%$, shift kerja siang sebesar $57,6 \%$, memiliki status gizi yang tidak normal sebesar $57,6 \%$ dan tingkat kelelahan kerja subjektif tinggi sebesar 73,3\%. Berdasarkan item pertanyaan dalam kuesioner, semua polisi lalu lintas yang menjadi responden selalu

merasa haus, malas berbicara, menguap saat bekerja, suara terasa serak dan berat di kaki.

Masa kerja sebagian besar responden lebih dari 10 tahun. Hal ini sejalan dengan penelitian Mukhlashin (2016) bahwa terdapat $64,9 \%$ operator SPBU memiliki masa kerja yang lama dimana pada penelitian ini sebagian besar responden mengalami kelahan kerja. Pekerjaan mengatur lalu lintas yang dilakukan setiap hari merupakan rutinitas monoton yang dapat meningkatkkan potensi kelelahan kerja subjektif pada polisi lalu lintas terutama pada responden yang memiliki status gizi yang tidak normal. Semua polisi lalu lintas yang menjadi responden menunjukkan gejala kurangnya konsumsi air putih seperti rasa haus, menguap saat bekerja, dan suara terasa serak. Kurangnya konsumsi air putih berhubungan dengan terjadinya kelelahan kerja.

\section{Hubungan Status Gizi dengan Kelelahan Kerja Subjektif}

Berdasarkan hasil penelitian diperoleh bahwa proporsi polisi lalu lintas di Kota Padang dengan status gizi tidak normal yang memiliki tingkat kelelahan kelelahan tinggi sebanyak $88,2 \%$ dibandingkan dengan dengan polisi lalu lintas dengan status gizi normal yang memiliki tingkat kelelahan kerja subjektif rendah sebanyak 46,2 \%. Hasil uji statistik Korelasi Kendall Tau didapatkan nilai $\mathrm{T}=0,736$ dengan nilai $\mathrm{Z}$ hitung 3,2 $(>1,96)$ artinya secara signifikan dengan alpha 0,05 bahwa ada hubungan positif kuat status gizi dengan kelelahan kerja subjektif polisi lalu lintas di Kota Padang Tahun 2018. Hal ini sejalan dengan penelitian Sabur (2007) pada petani bahwa status gizi seseorang mempengaruhi produktivitas kerja karena status gizi tidak normal akan mempercepat kelelahan kerja. Sedangkan menurut hasil penelitian Eralisa (2009) ada hubungan yang bermakna antara status gizi dengan kelelahan kerja pada pekerja bongkar muat di Pelabuhan Tapaktuan.

Menurut Tarwaka (2014) status gizi pekerja berarti nutrisi yang diperlukan pekerja untuk memenuhi kebutuhan sesuai jenis pekerjaannya. Status gizi seseorang dipengaruhi oleh aktivitas fisik dan pola konsumsi. Polisi lalu lintas memiliki rutinitas bekerja sejak pagi namun aktivitas fisik yang dulunya selalu dilakukan semakin berkurang. Walaupun pekerjaan sebagai polisi lalu lintas menyebabkan kelelahan fisik namun hal tersebut berbeda dengan aktifitas fisik seperti olahraga rutin. Pola konsumsi yang tidak tepat dapat mengganggu status gizi seseorang. Penerapan gizi kerja secara nyata telah memperbaiki, memelihara dan meningkatkan keadaan kesehatan dan produktivitas tenaga kerja.

\section{SIMPULAN}

1. Proporsi karakteristik polisi lalu lintas di Kota Padang yang menjadi responden adalah $66,7 \%$ memiliki umur $<35$ tahun, $60,0 \%$ masa kerja lebih dari 10 tahun, dan $57,6 \%$ shift kerja siang.

2. Proporsi polisi lalu lintas di Kota Padang yang menjadi responden dengan status gizi yang tidak normal adalah $56,7 \%$

3. Proporsi polisi lalu lintas di Kota Padang yang menjadi responden dengan dengan tingkat kelelahan kerja subjektif tinggi adalah $73,3 \%$ dimana semua polisi lalu lintas selalu merasa haus, malas berbicara dan berat di kaki. 
4. Ada hubungan positif kuat status gizi dengan kelelahan kerja subjektif polisi lalu lintas di Kota Padang Tahun 2018.

\section{SARAN}

1. Disarankan kepada Polresta Padang sebaiknya mulai menerapkan gizi kerja pada polisi lalu lintas

2. Disarankan kepada polisi lalu lintas untuk melakukan olahraga pagi sebelum melakukan rutinitas, konsumsi air putih yang cukup, dan mulai mengatur pola konsumsi yang tepat.

\section{UCAPAN TERIMA KASIH}

Akhir kata penulis mengucapkan terima kasih yang sebesar-besarnya kepada Yayasan Pendidikan Alifah Nur Ikhlas Padang dan civitas akademika STIKes Alifah Padang yang telah memberikan dukungan baik dana maupun moril sehingga penelitian ini selesai dengan sebaik-baiknya.

\section{DAFTAR PUSTAKA}

Iqbal, M.Arifin. 2014. Faktor-Faktor Yang Berhubungan Dengan Kelelahan Kerja Pada Karyawan Bagian Pemuatan PT Semen Padang Tahun 2014. Padang: Unand

Kodrat, Kimberly Febrina. 2011. Pengaruh Shift Kerja Terhadap Kelelahan Pekerja Pabrik Kelapa Sawit PT X Labuhan Batu. Jurnal Teknik Industri, Volume 12 No 2 Agustus 2011

Kuswana, Wowo Sunaryo. 2014. Ergonomi Dan Kesehatan Keselamatan Kerja. Bandung: PT Remaja Rosdakarya

Muizuddin, Ahmad. 2013. Hubungan antara Kelelahan dengan Produktivitas Kerja Pada Tenaga Kerja bagian Tenun di PT Alkatex Tegal Semarang: Universitas Negeri Semarang

Mukhlashin. 2016. Faktor Resiko Kelelahan Kerja Pada Operator SPBU di Kecamatan Grogol Kota Cilegon.
Russeng, Syamsiar. 2009. Status Gizi dan Kelelahan Kerja. Kajian Pada Pengemudi Bus Malam di Sulawesi Selatan dan Sulawesi Barat. Disertasi: Universitas Hassanuddin

Sabur, Made. 2007. Hubungan Antara Masa Kerja, Status Gizi dan Lama Kerja Terhadap Perasaan KelahanKerja Pada Petani Penyemprot Tanaman. Yogyakarta: UGM

Serdamayanti. 2011. Tata Kerja dan Produktivitas Kerja, Suatu Tinjauan Aspek Ergonomi Atau Kaitan antara Manusia dan Lingkungan. Bandung: Mandar Maju

. 2014. Sumber Daya Manusia dan Produktivitas Kerja. Bandung: Mandar Maju

Setiawati. 2010. Manajemen Kelelahan Kerja. Yogyakarta: Mandar Maju

Sukirman. 2000. Ilmu Gizi dan Aplikasinya. Jakarta: Departemen Pendidikan Nasional

Suma'mur. 2009. Keselamatan Kerja Dan Pencegahan Kecelakaan. Jakarta: Sagung Seto 2014. Hygiene Perusahaan dan Kesehatan (Hiperkes). Jakarta: Sagung Seto

Tarwaka. 2014. Ergonomi untuk Keselamatan, Kesehatan Kerja dan Produktivitas. Surakarta: Uniba Press

2015. Ergonomi Industri. Surakarta: Harapan Press

Wingjosoebroto. 2010. Kajian Ergonomi Dalam Perancangan Alat Bantu Proses Penyetelan Dan Pengelasan Produk Tangki Travo. Surabaya: ITS 